University of Nebraska - Lincoln

DigitalCommons@University of Nebraska - Lincoln

May 2004

\title{
Aspects of the ecology of a distinct population of Xenosaurus platyceps from Querétaro, México
}

Julio A. Lemos-Espinal

Laboratorio de Ecología, Unidad de Biología, Tecnología y Prototipos, Facultad de Estudios Superiores

Iztacala

Geoffrey R. Smith

Denison University, smithg@denison.edu

Royce E. Ballinger

University of Nebraska - Lincoln, rballinger1@unl.edu

Follow this and additional works at: https://digitalcommons.unl.edu/biosciherpetology

Part of the Other Animal Sciences Commons

Lemos-Espinal, Julio A.; Smith, Geoffrey R.; and Ballinger, Royce E., "Aspects of the ecology of a distinct population of Xenosaurus platyceps from Querétaro, México" (2004). Papers in Herpetology. 2.

https://digitalcommons.unl.edu/biosciherpetology/2

This Article is brought to you for free and open access by the Papers in the Biological Sciences at DigitalCommons@University of Nebraska - Lincoln. It has been accepted for inclusion in Papers in Herpetology by an authorized administrator of DigitalCommons@University of Nebraska - Lincoln. 
Published in Amphibia-Reptilia 25 (2004), pp. 204-210. Copyright (C) 2004 Koninklijke Brill NV. http://www.brill.nl/ Used by permission.

\section{Aspects of the ecology of a distinct population of Xenosaurus platyceps from Querétaro, México}

Julio A. Lemos-Espinal, Laboratorio de Ecología, Unidad de Biología, Tecnología y Prototipos, Facultad de Estudios Superiores Iztacala (UNAM), Av. De Los Barrios No.1, Los Reyes Iztacala, Tlalnepantla, Estado de México, C.P. 54090 México

Geoffrey R, Smith, Department of Biology, Denison University, Granville, Ohio 43023, USA; corresponding author, e-mail: smithg@denison.edu

Royce E. Ballinger, School of Biological Sciences, University of Nebraska-Lincoln, Lincoln, Nebraska 68588, USA 
Lizards in the genus Xenosaurus (Xenosauridae) show a flattened morphology, which is presumably an adaptation for their crevice-dwelling habits. Despite their general morphological similarities (Ballinger et al., 2000a), there is considerable variation among species and populations in ecological traits, and even populations of nominally the same species (e.g., $X$. grandis grandis and X. g. agrenon; Ballinger et al., 1995; Lemos-Espinal et al., 2003a) show variation, sometimes as much as between different species.

Populations of Xenosaurus are often geographically isolated (e.g., Pérez Ramos et al., 2000; Nieto Montes de Oca, 2001), and movement appears to be minimal (Lemos-Espinal et al., in press), and thus each population may be relatively isolated genetically and subject to local adaptation. Unfortunately, there are very few studied populations of Xenosaurus and in only one species has more than one population been studied (X. grandis; Ballinger et al., 1995; Lemos-Espinal et al., 2003a). In order to further our understanding of variation within this genus, we report on the ecology of a distinct population of $X$. platyceps from Querétaro. This is the second population of $X$. platyceps for which we have ecological data (see Lemos-Espinal et al., 1997b for a population of $X$. platyceps from Tamaulipas). These two populations are separated by $280 \mathrm{~km}$. Both populations are found in oak forest, although the Querétaro population is in denser forest than the Tamaulipas population. In addition, the area in which the Querétaro population lives is rockier and on a greater slope than the Tamaulipas population.

The study population was located $5 \mathrm{~km}$ North to the town of Tilaco, at Cerro de la Carnpana (Cañada de Acatitlán), Querétaro $\left(21^{\circ} 10^{\prime} 41.1^{\prime \prime N}, 99^{\circ} 10^{\prime} 4.1^{\prime} \mathrm{W} .1180 \mathrm{~m}\right.$ elevation). The vegetation at this site is low density oak forest (Quercus aristata, Q. castanea, Q. crassipes, Q. laeta, Q. laurina and Q. mexicana).

Lizards were collected by hand on 31 October 1998, 1 November 1998, 19-21 March 1999, 5-7 April 1999, 721 April 2000, 18-20 December 2000. We made several measurements and observations on each captured lizard. While in the field we measured snout-vent length with a clear plastic ruler (SVL; to nearest $\mathrm{mm}$ ), and body mass with a spring scale $(\mathrm{BM}$; to nearest $0.1 \mathrm{~g})$. In addition, body temperature $\left(\mathrm{T}_{\mathrm{b}}\right.$; nearest $\left.0.1^{\circ} \mathrm{C}\right)$ was taken with a quick-reading cloacal thermometer immediately upon capture. We also measured air temperature $\left(\mathrm{T}_{\mathrm{a}}\right.$; shaded therroometer $1 \mathrm{~cm}$ above substrate where individual first observed), and substrate temperature ( $\mathrm{T}_{\mathrm{s}}$; shaded thermometer touching substrate where individual first observed). We recorded the body position of each lizard (i.e., entirely inside the crevice, just head and front legs out of crevice).

We recorded several characteristics of the crevice in which lizards were found, including the thickness of the crack, the depth of the crevice, the height of the crevice from the ground, and the slope of the crack relative to horizontal ground. We measured the rock in which the crevice was found We noted whether the occupied crevice was found in the open sun, the shade, or in a sun/shade mosaic. We also counted the number of crevices and other potential refuges (e.g., holes) along five $50 \mathrm{~m}$ transects randomly located in the study site.

Lizards were collected by hand, humanely sacrificed by intracranial injection of alchohol and preserved shortly after collection (initially in 10\% formalin, and finally in 70\% ethanol; deposited in the herpetological collection of the Laboratorio de Ecología of the Unidad de Biología, Tecnología y Prototipos). We measured various morphological traits of preserved specimens to assess sexual dimorphism in these structures. We measured head width (HW; at the widest point), head length (HL; from anterior edge of ear to tip of snout), and femur length (FL; from knee to middle of pelvic region) to the nearest $0.01 \mathrm{~mm}$ using calipers. Sexual dimorphism in HW, HL, and FL was analyzed using analysis of covariance with SVL as the covariate after log transforming the dependent variables and the covariate (all three variables were significantly influenced by SVL). Unless noted, the slopes in the ANCOVAs were homogeneous and interaction terms removed from the final model.

We also dissected lizards to obtain information on litter size and diets. Diet items were identified to order, and the percent of prey volume for each taxon was calculated for each stomach (volume estimated by volumetric displacement; to nearest $\mathrm{mm}^{3}$ ). 
Table 1. Mean and Least Squares Mean (LSM) for the body measurements (in $\mathrm{mm}$ ) of male and female Xenosaurus platyceps from a population in Querétaro, México. Means are given $\pm 1 s_{\bar{x}}$. See text for abbreviations.

\begin{tabular}{|c|c|c|c|c|}
\hline & \multicolumn{2}{|c|}{ Male $(n=33)$} & \multicolumn{2}{|c|}{ Female $(n=40)$} \\
\hline & Mean & Least Squares Mean & Mean & Least Squares Mean \\
\hline SVL & $90.7 \pm 2.3$ & - & $98.6 \pm 1.7$ & - \\
\hline $\operatorname{logHW}$ & $1.282 \pm 0.013$ & $1.304 \pm 0.002$ & $1.305 \pm 0.007$ & $1.290 \pm 0.002$ \\
\hline $\log \mathrm{HL}$ & $1.307 \pm 0.013$ & $1.326 \pm 0.004$ & $1.323 \pm 0.007$ & $1.308 \pm 0.004$ \\
\hline $\log F L$ & $1.299 \pm 0.013$ & $1.320 \pm 0.003$ & $1.328 \pm 0.008$ & $1.311 \pm 0.003$ \\
\hline
\end{tabular}

Mean SVL (based on field measures) was $97.3 \pm 1.6 \mathrm{~mm}(n=74$; range 52 to $113 \mathrm{~mm})$. The average BM of individuals was $19.6 \pm 0.89(n=74$; range 4.0 to $30.0 \mathrm{~g})$. Females had larger mean SVLs than males (table $1 ; F_{1,71}=7.82, P=0.0066$ ). Males had wider heads than females after correcting for body size (table 1; HW: $F_{1,69}=13.70, P=0.0004$ ). Head width in males grew at a faster rate relative to SVL than did head width in females $\left(\operatorname{logSVL} *\right.$ sex interaction: $F_{1,69}=$ 14.82, $P=0.003$; slope $_{\text {male }}=1.065$, slope $\left._{\text {female }}=0.864\right)$. Males also had longer heads than females after correcting for body size (table 1; HL: $F_{1,70}=9.74, P=0.0026$ ). Males had larger FLs than females after correcting for body size (table $1 ; F_{1,70}=5.92, P=0.018$ ).

Most $X$. platyceps were completely within their crevice (36 of $78,46.2 \%$ ) or with only their head out of the crevice (33 of 78; 42.3\%). Six lizards $(7.7 \%$ ) were found with their heads and front legs outside the crevice. Three (3.8\%) were found completely out of a crevice.

The majority of $X$. platyceps were found in crevices (60 of 75; 80\%); however, 15 individuals were found in holes in the rock (20\%). Along transects, we found 7 holes $(29.2 \%)$ and 17 crevices (70.8\%). Lizard use of holes and crevices at the study site did not differ significantly from what was expected based on the availability of holes and crevices as determined by the transects, however, there was a trend to use crevices more often than expected (Yates' Corrected $\chi_{1}^{2}=2.72 ; P=0.099$ ).

We found lizards in crevices in the shade $38.7 \%$ of the time (29 of 75), crevices in the open $58.7 \%$ of the time (44 of 75), and in a shade-open mosaic $2.7 \%$ of the time ( 2 of 75 ).

The thickness of the crevice used or the diameter of the hole used by $X$. platyceps averaged $1.54 \pm 0.07 \mathrm{~cm}(n=60$, range 0.6 to $3.0 \mathrm{~cm})$. The depth of the crevices or holes was $21.5 \pm 1.1$ $\mathrm{cm}$ on average ( $n=72$, range 7 to $47.0 \mathrm{~cm}$ ). Xenosaurus platyceps individuals used crevices that had a mean height above ground level of $28.6 \pm 2.6 \mathrm{~cm}(n=75$, range 0 to $110 \mathrm{~cm})$.

The larger an individual (SVL), the larger the opening of the crevice in which it was found, however, body size explained very little of the variation in crevice or hole opening size $(n=56$, $r^{2}=0.065, P=0.058$; thickness $=0.53+0.10 \mathrm{SVL}$ ). No relationship was found between the size of a lizard and the depth of the crevice in which it was seen $\left(n=68, r^{2}=0.007, P=0.51\right)$. The height of a crevice was not related to the size of the individual living in it ( $n=71, r^{2}=0.026, P$ $=0.18)$. The size of the rock containing the crevice or hole was not related to the size of the lizard $\left(n=71, r^{2}=0.023, P=0.21\right)$. 
Table 2. Comparisons of mean and least squares mean body temperatures of Xenosaurus platyceps as a function of sex, body position, month, and solar insolation. Means are given $\pm 1 s_{\bar{x}}$ with $n$ in parentheses.

\begin{tabular}{lc}
\hline & Mean \\
\hline Sex & \\
Male (33) & $20.4 \pm 0.5^{\circ} \mathrm{C}$ \\
Female (43) & $20.7 \pm 0.5^{\circ} \mathrm{C}$ \\
Body Position & \\
All inside (36) & $18.6 \pm 0.5^{\circ} \mathrm{C}$ \\
Head out (33) & $21.9 \pm 0.4^{\circ} \mathrm{C}$ \\
Head and front legs out (6) & $23.0 \pm 0.8^{\circ} \mathrm{C}$ \\
Totally out (3) & $24.5 \pm 1.2^{\circ} \mathrm{C}$ \\
Month & \\
February (11) & $17.7 \pm 0.3^{\circ} \mathrm{C}$ \\
March (25) & $17.3 \pm 0.1^{\circ} \mathrm{C}$ \\
April (24) & $23.2 \pm 0.3^{\circ} \mathrm{C}$ \\
July (7) & $24.6 \pm 0.3^{\circ} \mathrm{C}$ \\
October (6) & $21.1 \pm 0.3^{\circ} \mathrm{C}$ \\
November (5) & $24.0 \pm 0.4^{\circ} \mathrm{C}$ \\
Cover & \\
Open (44) & $20.5 \pm 0.4^{\circ} \mathrm{C}$ \\
Open/Shade mosaic (2) & $20.9 \pm 1.9^{\circ} \mathrm{C}$ \\
Shade (29) & $20.2 \pm 0.6^{\circ} \mathrm{C}$ \\
\hline
\end{tabular}

Seventy-six individuals were found alone in their crevice $(97.4 \%)$. One pair $(2.6 \%)$ was found, and it was a female-neonate pair.

Mean $\mathrm{T}_{\mathrm{b}}$ was $20.6 \pm 0.4 \mathrm{C}(n=78$; range $=16.2$ to $26.4 \mathrm{C})$. Mean $\mathrm{T}_{\mathrm{a}}$ was $18.7 \pm 0.3 \mathrm{C}(n=$ 78 ; range $=15.4$ to $24.2 \mathrm{C})$, and mean $\mathrm{T}_{\mathrm{s}}$ was $18.8 \pm 0.3 \mathrm{C}(n=78$; range $=15.6$ to $24.2 \mathrm{C})$. Air temperature and $\mathrm{T}_{\mathrm{s}}$ were highly positively correlated $\left(n=78 . r^{2}=0.98, P<0.0001 ; \mathrm{T}_{\mathrm{s}}=-0.53+\right.$ $\left.1.02 \mathrm{~T}_{\mathrm{a}}\right)$. Body temperature was significantly influenced by both $\mathrm{T}_{\mathrm{a}}\left(n=78, r^{2}=0.62, P<0.0001\right.$; $\left.\mathrm{T}_{\mathrm{b}}=2.23+0.98 \mathrm{~T}_{\mathrm{a}}\right)$ and $\mathrm{T}_{\mathrm{s}}\left(n=78, r^{2}=0.65, P<0.0001 ; \mathrm{T}_{\mathrm{b}}=1.01+1.04 \mathrm{~T}_{\mathrm{s}}\right)$.

Males and females had similar $\mathrm{T}_{\mathrm{b}} \mathrm{s}$ (table $2 ; F_{1,74}=0.17, P=0.63$ ). Lizards that were found entirely within the crevice had lower $\mathrm{T}_{b} \mathrm{~s}$ than lizards with any part of their body outside the crevice and the individuals found completely out of a crevice had the highest $\mathrm{T}_{\mathrm{b}} \mathrm{s}$ (table 2; Kruskal-Wallis: $\left.\mathrm{H}_{3}=26.5, P<0.0001\right)$. Body temperatures did not differ between the six months for which data are available (table 2; Kruskal-Wallis: $\mathrm{H}_{5}=63.3, P<0.0001$ ). Lizards whose crevices were in the open, open/shade mosaic, and shade did not differ in mean $\mathrm{T}_{\mathrm{b}}$ (table 2; KruskalWallis: $\mathrm{H}_{2}=0.28, P=0.87$ ).

We used stepwise regression to determine which aspects, if any, of a crevice were related to $\mathrm{T}_{\mathrm{b}}, \mathrm{T}_{\mathrm{a}}$, and $\mathrm{T}_{\mathrm{s}}$. Of the four crevice characteristics measured (thickness, height, depth, and rock size), thickness was retained in the regression model for $\mathrm{T}_{\mathrm{s}}\left(n=59, r^{2}=0.071, P=0.041 ; \mathrm{T}_{\mathrm{s}}=\right.$ $16.8+1.23$ thickness). For $\mathrm{T}_{\mathrm{a}}$, the size of the crevice or hole opening was retained in the model $\left(n=59, r^{2}=0.075, P=0.04 ; \mathrm{T}_{\mathrm{a}}=16.6-1.32\right.$ thickness $)$. Body temperature was not affected by any of the crevice characteristics. 
Table 3. Diet of Xenosaurus platyceps from Querétaro, México.

\begin{tabular}{lccccc}
\hline Prey Taxon & $\begin{array}{c}\text { Number of } \\
\text { Stomachs }\end{array}$ & $\begin{array}{c}\text { Number of } \\
\text { Items }\end{array}$ & $\begin{array}{c}\text { Percent of } \\
\text { Diet }\end{array}$ & $\begin{array}{c}\text { Total Volume } \\
\left(\mathrm{cm}^{3}\right)\end{array}$ & $\begin{array}{c}\text { Percent of Diet } \\
\text { by Volume }\end{array}$ \\
\hline $\begin{array}{l}\text { Araneae } \\
\text { Insecta }\end{array}$ & 4 & 4 & 2.14 & 0.38 & 0.60 \\
$\quad \begin{array}{c}\text { Coleoptera } \\
\quad \text { Adults }\end{array}$ & 15 & 26 & 13.9 & 4.73 & 7.46 \\
$\quad \begin{array}{l}\text { Larvae } \\
\text { Hemiptera }\end{array}$ & 3 & 3 & 1.6 & 0.61 & 0.96 \\
$\quad$ Larvae & 1 & 1 & 0.53 & 0.9 & 1.42 \\
$\begin{array}{c}\text { Isoptera } \\
\quad \text { Termitidae }\end{array}$ & 1 & 1 & 0.53 & 0.8 & 1.26 \\
$\begin{array}{c}\text { Lepidoptera } \\
\text { Larvae }\end{array}$ & 16 & 16 & 8.55 & 9.1 & 14.21 \\
$\begin{array}{c}\text { Orthoptera } \\
\text { Acrididae }\end{array}$ & 66 & 136 & 72.73 & 46.8 & 73.91 \\
\hline
\end{tabular}

The two smallest females with embryos were $92 \mathrm{~mm}$ and $95 \mathrm{~mm}$ SVL. Mean litter size was $2.7 \pm 0.3(n=15$, range $=1$ to 6$)$. The most common litter size was $3(7$ of $15 ; 46.7, \%)$. There. was no significant relationship between female SVL and litter size (Spearman's Correlation: $n=$ $15, \mathrm{Z}=-0.551, P=0.58)$.

The overall sex ratio was 43 females: 33 males, which is not different from 1:1 $\left(\chi_{1}^{2}=1.32, P\right.$ $=0.25)$.

The diet of $X$. platyceps ( 74 stomachs examined) consisted primarily of insects (table 3 ). On the basis of the number of items and the volume of items consumed, as well as their frequency of occurrence in stomachs, orthopterans, and in particular Acridids, were by far the most important prey items. Coleopterans and lepidopterans were of secondary importance. Of the 74 stomachs examined, 5 (6.8\%) were empty.

Female Xenosaurus platyceps in Querétaro were larger than males. This is similar to the other population of $X$. platyceps from Tamaulipas. Given the 1:1 sex ratio, it is unlikely that differential mortality of males and females contributed to sexual dimorphism. Male $X$. platyceps had larger heads than females, as did X. platyceps from Tamaulipas. Although the evolutionary origin of sexual dimorphism in this species is not known, evidence from $X$. newmanorum suggests it may be related to intrasexual selection involving male-male aggression (Smith et al., 1997).

It is noteworthy that we observed three individuals of $X$. platyceps completely outside any crevice or hole. In previous studies, no Xenosaurus had been observed completely outside their crevice (Ballinger et al., 1995; Lemos-Espinal et al., 1996, 1997b, 1998, 2003a), although we know they must occasionally leave their refuges to move (Lemos-Espinal et al., in press for $X$. newmanorum). Such behavior may be related to movement or it may be related to body temperature or thermoregulation since individuals that were completely outside their crevices or holes had the highest $\mathrm{T}_{\mathrm{b}}$ although sample sizes were small.

The vast majority of $X$. platyceps in Querétaro occurred alone, but X. platyceps from Tamaulipas show some degree of aggregation (Lemos-Espinal et al., 1997b). Our finding of one fe- 
male-neonate pair may be related to parental care (Lemos-Espinal et al., 1997a, b).

Mean $\mathrm{T}_{\mathrm{b}}$ of $X$. platyceps in Querétaro is among the lowest observed in the genus, but conspecifics from Tamaulipas had a lower mean $T_{b}$ (Lemos-Espinal et al., 1997b). These two conspecific populations were similar in their relative independence of $\mathrm{T}_{b}$ from environmental temperatures (Lemos-Espinal et al., 1997b).

Crevice use did not affect $\mathrm{T}_{b} \mathrm{~s}$ of $X$. platyceps in our study. The nature of the crevices and holes used by $X$. platyceps, or the large rocks the crevices or holes occur in, may limit their usefulness for or impact on thermoregulation (e.g., Huey et al., 1989; Webb and Shine, 1998).

Females in this population of $X$. platyceps appear to mature around $92-95 \mathrm{~mm} \mathrm{SVL}$. This is the smallest SVL at maturity among those Xenosaurus for which we have data (Ballinger et al., 2000b; Lemos-Espinal et al., 2003a). In particular, maturity occurs at a substantially smaller SVL (by 6-9 $\mathrm{mm}$ ) than in the population of $X$. platyceps in Tamaulipas (Ballinger et al., 2000b). Additional study is necessary to determine if these differences are the result of differences in the proximate environment or reflect genetic differences in these populations.

Mean litter size for this population was very similar to the litter sizes of most other Xenosaurus (Ballinger et al., 2000b; Lemos-Espinal et al., 2003a).

The diet of $X$. platyceps from Querétaro is similar to the diet of $X$. platyceps in Tamaulipas, as well as the other Xenosaurus for which we have diets (Ballinger et al., 1995; Lemos-Espinal et al., 2003b).

Acknowledgements. We thank two anonymous reviewers for their comments that helped improve this note. The research described herein was approved and supported by the Consejo Nacional de Ciencia y Tecnología (CONACyT) and the Programa de Apoyo a Proyectos de Investigación Tecnológica de la Dirección General de Asuntos del Personal Academico de la UNAM (PAPIIT). This study was supported by a grant from DGAPA No. IN216199 and No. IN200103, and CONACyT No. 4O797-Q, to JAL.

\section{References}

Ballinger, R.E.. Lemos-Espinal, J.A., Sanoja-Sarabia, S., Coady, N.A. (1995): Ecological observations of the lizard, Xenosaurus grandis in Cuautlapán, Veracruz, México. Biotropica 27: 128-132.

Ballinger, R.E., Lemos-Espinal, J.A., Smith, G.R. (2000b): Reproduction in females of three species of crevice-dwelling lizards (genus Xenosaurus) from Mexico. Stud. Neotrop. Fauna Environ. 35: 179183.

Ballinger, R.E., Smith, G.R., Lemos-Espinal, J.A. (2000a): Xenosaurus. Cat. Amer. Amphibia-Reptilia 712: $1-3$.

Huey, R.B., Peterson, C.R., Arnold, S.J., Porter, W.P. (1989): Hot rocks and not-so-hot rocks: retreat-site selection by garter snakes and its thermal consequences. Ecology 70: 931-944.

Lemos-Espinal, J.A., Smith, G.R., Ballinger, R.E. (1996): Natural history of the Mexican knob-scaled lizard, Xenosaurus rectocollaris. Herpetol. Nat. Hist 4: 151-154.

Lemos-Espinal, J.A., Smith, G.R., Ballinger, R.E. (1997a): Neonate-female associations in Xenosaurus newmanorum. a case of parental care in a lizard? Herpetol. Rev. 28: 22-23.

Lemos-Espinal, J.A., Smith, G.R., Ballinger, R.E. (1997b): Natural history of Xenosaurus platyceps, a 
crevice-dwelling lizard from Tamaulipas, Mexico. Herpetol. Nat. Hist. 5: 181-186.

Lemos-Espinal, J.A., Smith, G.R., Ballinger, R.E. (1998): Thermal ecology of the crevice-dwelling lizard, Xenosaurus newmanorum. J. Herpetol. 32: 141-144.

Lemos-Espinal, J.A., Smith, G.R., Ballinger, R.E. (2003a): Ecology of Xenosaurus grandis agrenon, a knob- scaled lizard from Oaxaca, México. J. Herpetol. 37: 192-196.

Lemos-Espinal, J.A., Smith, G.R., Ballinger, R.E. (2003b): Diets of three species of knob-scaled lizards (genus Xenosaurus ) from México. Southwest. Nat. 48: 119-122.

Lemos-Espinal, J.A., Smith, G.R., Ballinger, R.E. (in press): Variation in growth and demography of a knob-scaled lizard (Xenosaurus newmanorum: Xenosauridae) from a seasonal tropical environment in México. Biotropica.

Nieto-Montes de Oca, A., Campbell, J.A., Flores-Villela, O. (2001): A new species of Xenosaurus (Squamata: Xenosauridae) from the Sierra Madre del Sur of Oaxaca, Mexico. Herpetologica 57: 32-47.

Pérez Ramos, E., Saldaña de la Riva, L., Campbell, J.A. (2000): A new allopatric species of Xenosaurus (Squamata: Xenosauridae) from Guerrero, Mexico. Herpetologica 56: 500-506.

Smith, G.R., Lemos-Espinal, J.A., Ballinger, R.E. (1997): Sexual dimorphism in two species of knobscaled lizards (genus Xenosaurus ) from Mexico. Herpetologica 53: 200-205.

Webb, J.K., Shine, R. (1998): Using thermal ecology to predict retreat-site selection by an endangered snake species. Biol. Conserv. 86: 233-242

Submitted April 2003; accepted June 2003. 